\title{
STATISTICAL ANALYSIS ON FACTORS THAT CONTRIBUTE TO POST HARVEST LOSSES OF CROPS IN RURAL AREA AT NKWANTA DISTRICTS, VOLTA REGIONS, GHANA
}

\author{
Michael Dovlo *1), Etornam Kwame Kunu ${ }^{1)}$, Nur Ahmad Rudin ${ }^{2)}$ \\ ${ }^{1)}$ Department of Statistics, University of Cape Coast, Cape Coast, Ghana \\ 2) Department of Tropical Biology, Faculty of Biology, Universitas Gadjah Mada, Yogyakarta, \\ Indonesia \\ *) Corresponding Author Email: mdovlo@yahoo.com
}

\begin{abstract}
The study was conducted to assess the factors that contribute to post harvest losses of farm produces in the Nkwanta Districts, Volta Region, Ghana. Data was collected from 250 farmers in the district using a structured questionnaire. The last item on the questionnaire examined the level of agreement attached to various factors influencing post harvest losses in the district on a five point Likert scale. Multivariate factor analysis method was used in the analysis. The results indicated that about $87.2 \%$ of the total respondent experience of post harvest losses and there are five salient factors that influence post harvest losses. Difficulties in market accessibility related factors was the most important factor of all. Another important factors accountable for post harvest losses are lack of knowledge and technology related factors, lack of storage facilities and poor packaging, the poor road network, and labour cost. It is therefore recommended that different forms of training and information should be made available for farmers. Also, the establishment of the factories and storage facilities at farming communities should be put in place in order to reduce post harvest losses by way of processing and storage of the excess produces at the local level.
\end{abstract}

Keywords: crop; Ghana; post harvest losses; rural area

\section{INTRODUCTION}

Agriculture sector in Ghana plays an essential role in term of gross domestic product for country. Olayemi et al. (2012) in their study in Nigeria find out that the agriculture sector contribute more than $30 \%$ to total GDP of the country. Growers of perishable products, such as fresh fruits, vegetables and other crops very often face post harvest losses. Based on Verma and Singh (2004), the total losses in vegetables can reach $25 \%$ of total production. This could means that GDP of the country may also reduced by $25 \%$. Post-harvest activities important to maintain the products quality to stay prime up until the hands consumers, press losses due to depreciation and damage, extend power save and increase economical value of agricultural products (Shiddieqy and Widiani, 2012). Mistakes in handling the harvest and post-harvest can result in enormous losses (Darwis, 2018).

In Ghana, improving the production capacities of farmers has been serious attempt. However, the sector is overwhelmed with high levels of post harvest losses. A study conducted by Robinson and Kolavalli (2010) indicated that post harvest losses are highest for tomatoes and lettuce which reach $20 \%$ after 5 days of harvesting. More than 510,000 metric tons of tomato produced annually in Ghana and post harvest losses about 153,000 metric tons (30\%). Farmers can produce good quality of vegetables and fruits, but if they do not have a fast, dependable, and equitable means 
of getting such commodities to the consumer, losses will be extensive. Research study conducted by Olayemi et al. (2012) reveals that the mean value of post harvest losses in Nigeria were $35 \%$ for fish, $37 \%$ for yam, $33 \%$ for vegetable, $27.67 \%$ for cassava, $27 \%$ for plantain, $20.33 \%$ for maize. Losses experienced are serious problem and important to be minimized. This has confirm that growers really expriences post harvest losses during their cropping seasons. This problem can found in many locations within the country. It is accentuated by lack of communication and market information between producers (farmers) and receivers (distributors and consumers), however there is no empirical study that identified factors that contributing to the post harvest losses in Ghana. Karim and Wee (1996) said that well managed on post harvest activities led to higher yields of vegetable products and profits to producers. The post harvest practices needs given much attention to production process. According to Tefera (2012) post harvest losses contribute to increase of food prices by decrease of supply to the market. This study aimed towards the development of a better understanding and exploring the determinants factors contributing to post harvest loses in farming areas in Ghana.

\section{METHOD}

The study conducted with cross-sectional survey design and descriptive methods. The study location was on Nkwanta District in Volta Region, Ghana. The population for study cover all farming age group in the district. The target population was farmers who have farmed at least for past three years before data collection. A sample of 250 farmers was conveniently used for sample and completed the questionnaire on the factors accountable for post harvest losses representing $100 \%$ response rate. The respondents which represent 16.4\% were females whiles 209 of them which represent $83.6 \%$ were males, the result again reveal that $5.2 \%$ of the farmers were below 30 years of age, $15.2 \%$ were between the ages of $31-35,29.2 \%$ were between the ages of $36-40$ and $50.4 \%$ of them were above 40 . The distribution of respondents according to their level of education appears to have majority $54.4 \%$ of the respondents having informal education whiles $22.8 \%$ and $16.8 \%$ were the farmers having primary and secondary education respectively. This implies that the views leading to conclusion drawn from this study could be largely attributed to respondents with informal and SHS certificate farmers.

Data collection was obtained by interview and fill a questionnaire though several vegetable and other crops that cultivated in different seasons. The present study was made on the factors that contribute to post harvest losses among the farmers in the district. The questionnaire consists of two parts. The first parts consisted of demographic information such as age, gender, years of farming and methods of farming of the respondents. The second parts contain sixteen factors perceived to influence post harvest losses. Data analysis was done for each parts from questionnaire. The preliminary analysis (first parts) was done to assess the distribution frequency from various items using descriptive univariate analysis and represented with distribution tables, graph and charts. The further analysis (second parts) was used to describe original that influenced the post harvest losses. SPSS and Microsoft Excel software was used as tool for data analysis.

\section{RESULTS AND DISCUSSION}

Based on the responses from the farmers, figure 1 indicated that $87.2 \%$ of the total respondents experience of post harvest losses, which the rest $12.8 \%$ indicated that do not experience of post harvest losses. Therefore it is necessary to investigate the factors contributing post harvest losses. 


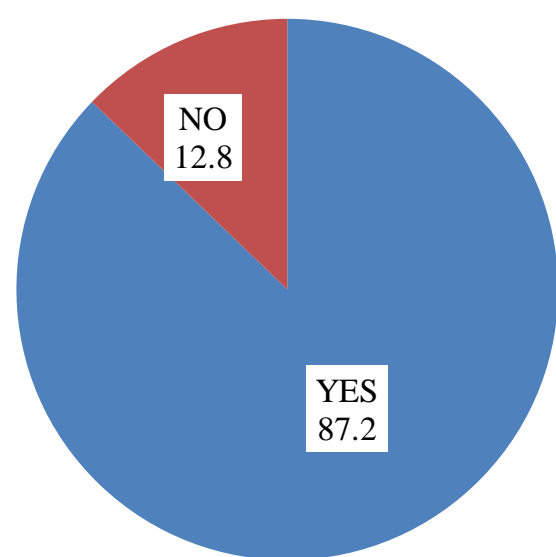

Figure 1. Experience of Post harvest Losses

Definition of factors contribute the post harvest losses are the size of the farm (X1), labour cost (X2), cost of transportation (X3), inadequate market for the crop (X4), fertilizer and chemical used (X5), quality of the crop (X6), method of storage (X7), the temperature of the area (X8), improper price regulation (X9), inadequate information about the crop (X10), method of farming (X11), lack of technology to process the crop (X12), poor farm management (X13), improper market facilities (X14), poor packaging (X15), and poor road network (X16). Data analysis using realiability test, correlation among the sixteen indicator variables, and KMO and Bartlett's Test.

Table 1. Reliability Analysis

\begin{tabular}{lc}
\hline Measure & Value \\
\hline Cronbach's Alpha & 0.775 \\
Number of items & 16 \\
\hline
\end{tabular}

The alpha value of 0.775 displays a good storey of consistency in the data generated for factor psychoanalysis. This advance points out that the scale used is unidimensional and hence responses to similar or homogenous pointers are almost 77 . $5 \%$ of the time coherent with each over the counter from Table 1.

Table 2 exposes the inter-correlations among the variables, implying that the indicator variables correlate rather greatly with single another. This multicollinearity among the variables should be indicate that there are similarities in the respondents' ratings of the sixteen limiting constituents lining the agriculture sector in the district. The correlation coefficient must be 0.3 or better because anything drop would hint a really faint accord between the variables. So, the highest coefficient of expansion esteem of 0.68 recorded between $\mathrm{X} 12$ and $\mathrm{X} 10$; points out that almost $68 \%$ of the respondents rated poor information almost the crop and lack of technology and miss of application to crop process are most the identical. There is a relatively high-pitched coefficient of expansion between variable X1 and X1, X14 and X15, X4 and X5, X8 and X12, X10 and $\mathrm{X} 11$, and variable $\mathrm{X} 8$ and $\mathrm{X} 10$. 
Table 2. Correlation among the Sixteen Indicator Variables

\begin{tabular}{|c|c|c|c|c|c|c|c|c|c|c|c|c|c|c|c|c|}
\hline & $\mathrm{X} 1$ & $\mathrm{X} 2$ & X3 & $\mathrm{X} 4$ & $\mathrm{X} 5$ & $\mathrm{X} 6$ & $\mathrm{X} 7$ & $\mathrm{X} 8$ & X9 & $\mathrm{X} 10$ & $\mathrm{X} 11$ & $\mathrm{X} 12$ & $\mathrm{X} 13$ & $\mathrm{X} 14$ & $\mathrm{X} 15$ & $\mathrm{X} 16$ \\
\hline $\mathrm{X} 1$ & 1.00 & & & & & & & & & & & & & & & \\
\hline X2 & 0.65 & 1.00 & & & & & & & & & & & & & & \\
\hline X3 & 0.26 & 0.28 & 1.00 & & & & & & & & & & & & & \\
\hline $\mathrm{X} 4$ & 0.14 & 0.12 & 0.32 & 1.00 & & & & & & & & & & & & \\
\hline X5 & 0.29 & 0.28 & 0.40 & 0.51 & 1.00 & & & & & & & & & & & \\
\hline $\mathrm{x} 6$ & 0.34 & 0.31 & 0.30 & 0.23 & 0.39 & 1.00 & & & & & & & & & & \\
\hline $\mathrm{X} 7$ & 0.18 & 0.21 & 0.34 & 0.20 & 0.31 & 0.27 & 1.00 & & & & & & & & & \\
\hline X8 & 0.19 & 0.20 & 0.36 & 0.21 & 0.22 & 0.26 & 0.37 & 1.00 & & & & & & & & \\
\hline X9 & 0.24 & 0.20 & 0.13 & 0.17 & 0.22 & 0.10 & 0.29 & 0.18 & 1.00 & & & & & & & \\
\hline $\mathrm{X} 10$ & 0.17 & 0.14 & 0.36 & 0.19 & 0.43 & 0.15 & 0.22 & 0.43 & 0.32 & 1.00 & & & & & & \\
\hline $\mathrm{X} 11$ & 0.14 & 0.18 & 0.12 & 0.20 & 0.24 & 0.10 & 0.13 & 0.27 & 0.24 & 0.47 & 1.00 & & & & & \\
\hline $\mathrm{X} 12$ & 0.14 & 0.12 & 0.33 & 0.11 & 0.25 & 0.14 & 0.27 & 0.49 & 0.19 & 0.68 & 0.39 & 1.00 & & & & \\
\hline $\mathrm{X} 13$ & 0.33 & 0.25 & 0.20 & 0.21 & 0.21 & 0.29 & 0.22 & 0.28 & 0.13 & 0.15 & 0.14 & 0.24 & 1.00 & & & \\
\hline $\mathrm{X} 14$ & 0.08 & 0.08 & -0.01 & 0.04 & 0.18 & 0.09 & 0.04 & -0.02 & 0.02 & 0.03 & -0.03 & 0.06 & -0.09 & 1.00 & & \\
\hline X15 & 0.11 & 0.14 & -0.10 & 0.03 & 0.12 & 0.08 & -0.04 & -0.01 & 0.05 & -0.01 & -0.01 & 0.03 & -0.03 & 0.53 & 1.00 & \\
\hline $\mathrm{X} 16$ & -0.03 & 0.02 & -0.06 & 0.03 & 0.12 & 0.06 & -0.07 & 0.00 & 0.04 & 0.06 & -0.03 & -0.04 & -0.02 & 0.01 & 0.24 & 1.00 \\
\hline
\end{tabular}

Although there are some few negative correlations among the variables, viewing an opposite accord, none of them look to be high-pitched. The information obtained from the correlation matrix can be used to construct factor groupings that mightiness exist in the locate. The factor groupings that may be obtained are pictured beneath:

$f_{1}=\{X 1, X 2, X 6, X 13\}$

$$
\begin{aligned}
& f_{2}=\{X 3, X 5, X 6, X 7, X 8, X 10, X 12\} \\
& f_{4}=\{X 9, X 10\} \\
& f_{6}=\{X 14, X 15\}
\end{aligned}
$$$$
f_{3}=\{X 4, X 5\}
$$$$
f_{5}=\{X 10, X 11, X 12\}
$$

The groupings indicate that there are similarities between variables in the identical group; so they have high-pitched loadings on each over the counter in the coefficient of expansion matrix. Their probabilities would be also explained in the succeeding productions. The next output investigates the appropriateness of factor psychoanalysis.

Table 3. KMO and Bartlett's Test

\begin{tabular}{llr}
\hline Kaiser-Meyer-Olkin Measure of Sampling Adequacy. & 0.750 \\
Bartlett's Test of Sphericity & Approx. Chi-Square & 1075.011 \\
& Df & 120 \\
& Sig. & 0.000 \\
\hline
\end{tabular}

The KMO value of 0.750 proposes that the test is adapted for factorisation This implies that factor psychoanalysis is capture and would allow estimable resolution. The Bartlett's test is substantial with a p-value of 0.00 indicate that the variables are correlated. The Approx. Chi-Square besides shown in the table 3 with big chi-square value of 1075.011 which is relatively big plenty to support factor psychoanalysis.

This discoveries were in consistency with the study conducted by (Kereth et al., 2013) establish out that bad infrastructure from farm to the marketplace contribute for great losings in the market including scratchy roadsteads, means of transport, and packaging materials, again the current findings were in line with the findings by World 
Bank (2011) in low income nations, pre-harvesting management, processing, storage infrastructure and market facilities were either not available or were inadequate.

\section{Extraction of factors and factor interpretation}

The Eigen value better than single rule and the scree plot would serve as a basis for factor origin; the total variance explained outturn presents the number of factors worthy for origin using the Eigen value rule.

Table 4. Total variance explained

\begin{tabular}{lccc}
\hline Component & Total & \% of Variance & Cumulative \% \\
\hline 1 & 5.401 & 28.262 & 28.262 \\
2 & 2.128 & 11.137 & 39.399 \\
3 & 1.832 & 9.584 & 48.984 \\
4 & 1.576 & 8.244 & 57.228 \\
5 & 1.319 & 6.902 & 64.130 \\
6 & 1.166 & 6.099 & 70.229 \\
7 & 1.082 & 5.66 & 75.889 \\
8 & 0.829 & 4.336 & 80.225 \\
9 & 0.788 & 4.123 & 84.349 \\
10 & 0.639 & 3.342 & 87.691 \\
11 & 0.585 & 3.063 & 90.754 \\
12 & 0.52 & 2.72 & 93.474 \\
13 & 0.38 & 1.99 & 95.464 \\
14 & 0.345 & 1.803 & 97.267 \\
15 & 0.31 & 1.624 & 98.891 \\
16 & 0.212 & 1.109 & 100 \\
\hline
\end{tabular}

From Table 4, the Eigen value better than single rule is used to influence the act of components adapted for explaining the data variations. Out of the sixteen indicators variables, the six and seven eigen-values look to be importantly better than single; two of the eigen-values, though better than single are insignificant. This points out that only five components are adequate with cumulative percentage of 64.130. Fair as the correlation matrix showed earlier that there are seven main components, the total variance explained by these constituent gives a reason for about $75.89 \%$ of variations. The most essential constituent gives a reason for $28.3 \%$, the next $11.1 \%$, followed by $5.6 \%, 8.2 \%$, and lastly $6.9 \%$ with the eigen-values of $5.4,2.1,1.8,1.5$, and 1.3 severally.

From figure 2, the scree plot proposes that sixteen components are suitable for extraction; this can be seen that the plot displays a sheer from the first to the first to fifth factor; from the sixth to the sixteen constituents it shows a easy declivity. This proposes that the act of constituents that must be extracted not exceed five. 


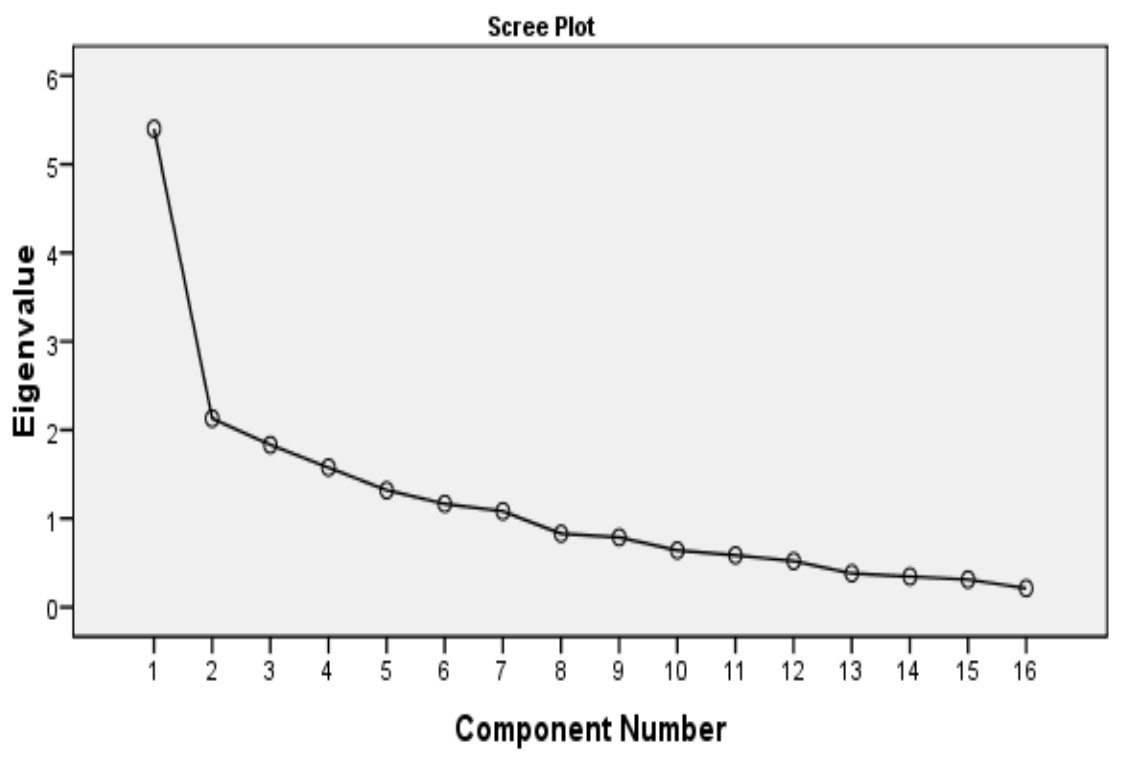

Figure 2. Scree plots of the factors

Table 5. Unrotated Factor Matrix

\begin{tabular}{lccccc}
\hline & \multicolumn{5}{c}{ Component } \\
\hline X1 & $\mathbf{1}$ & $\mathbf{2}$ & $\mathbf{3}$ & $\mathbf{4}$ & $\mathbf{5}$ \\
X2 & $\mathbf{1 . 0 2}$ & $\mathbf{- 0 . 7 0}$ & -0.30 & 0.23 & -0.08 \\
X3 & $\mathbf{0 . 9 1}$ & $\mathbf{- 0 . 6 6}$ & -0.18 & 0.28 & -0.18 \\
X4 & $\mathbf{0 . 6 1}$ & 0.37 & -0.07 & 0.10 & -0.30 \\
X5 & $\mathbf{0 . 5 0}$ & 0.41 & 0.25 & -0.04 & -0.04 \\
X6 & $\mathbf{0 . 7 3}$ & 0.31 & 0.40 & 0.08 & -0.10 \\
X7 & $\mathbf{0 . 9 7}$ & -0.01 & 0.33 & -0.90 & -0.27 \\
X8 & 0.47 & 0.29 & -0.05 & 0.03 & -0.12 \\
X9 & 0.41 & 0.30 & -0.05 & 0.12 & 0.08 \\
X10 & 0.31 & 0.09 & 0.00 & 0.28 & 0.04 \\
X11 & 0.45 & 0.45 & 0.07 & 0.43 & 0.06 \\
X12 & 0.24 & 0.19 & -0.02 & 0.23 & 0.05 \\
X13 & 0.37 & 0.39 & -0.03 & 0.33 & 0.15 \\
X14 & $\mathbf{0 . 7 3}$ & 0.09 & -0.50 & -0.35 & $\mathbf{0 . 8 8}$ \\
X15 & 0.10 & -0.19 & 0.48 & 0.15 & 0.03 \\
X16 & 0.14 & -0.42 & $\mathbf{0 . 7 6}$ & 0.20 & 0.34 \\
\hline
\end{tabular}

The un-rotated factor matrix presents hints to the interpretation of the underlying constituents that looks for explicate the constituents that contribute to post harvest losings of crops in rural area. At a cut-off point of 0.5 , the first factor is greatly loaded on X1 (the farm size), X2 (labour cost), X3 (cost of transportation), X4 (inadequate marketplace for the crop), X5 (fertilizer and chemical used), X6 (quality of the crop), $\mathrm{X} 13$ (poor farm management). From the correlation matrix, these indicators address to 
have commonality among each other. These nevertheless look to be related to the expenses payment and farm management.

The second factor comes to be greatly loaded on X1 (quality of the crop), X2 (labour cost). This factor rotates to be related to the cost of production. The third factor is also quite highly loaded significantly by the indicator. The highest loading there is from the indicator X15 (Poor packaging) and X16 (Poor road network). This indicator is associated with the packaging and access to proper roads. The forth factor is also has high-pitched loadings from two indicators, X6 (quality of the crop). This nevertheless associates to the quality of the crops. Lastly, the fifth factor is greatly loaded on X1 (the farm size) and X13 (Poor farm management). This factor is related the size a form and it management.

Below is the rotated factor matrix. This would offer an opportunity to have simpler factor constitution that can be meaningfully took.

Table 6. Rotated Factor Matrix

\begin{tabular}{lccccc}
\hline \multicolumn{5}{c}{ Component } \\
\hline & $\mathbf{1}$ & $\mathbf{2}$ & $\mathbf{3}$ & $\mathbf{4}$ & $\mathbf{5}$ \\
\hline X1 & 0.099 & 0.114 & 0.860 & 0.086 & -0.031 \\
X2 & 0.098 & 0.107 & 0.835 & 0.110 & -0.004 \\
X3 & 0.241 & 0.619 & 0.163 & -0.077 & -0.271 \\
X4 & 0.072 & 0.750 & -0.002 & -0.042 & 0.203 \\
X5 & 0.247 & 0.728 & 0.168 & 0.162 & 0.206 \\
X6 & -0.012 & 0.543 & 0.410 & 0.092 & -0.028 \\
X7 & 0.237 & 0.473 & 0.176 & 0.017 & -0.346 \\
X8 & 0.549 & 0.332 & 0.129 & -0.021 & -0.261 \\
X9 & 0.434 & 0.064 & 0.305 & -0.009 & 0.181 \\
X10 & 0.842 & 0.227 & 0.015 & 0.025 & 0.032 \\
X11 & 0.693 & 0.009 & 0.129 & -0.080 & 0.146 \\
X12 & 0.810 & 0.144 & 0.010 & 0.080 & -0.225 \\
X13 & 0.146 & 0.267 & 0.479 & -0.199 & -0.080 \\
X14 & -0.008 & 0.082 & -0.017 & 0.888 & -0.106 \\
X15 & 0.007 & -0.027 & 0.110 & 0.825 & 0.245 \\
X16 & 0.043 & 0.094 & -0.016 & 0.094 & 0.801 \\
\hline
\end{tabular}

After the rotation, it is observed that the loadings on the first factor are now on X8 (the temperature of the area), X10 (inadequate information about the crop), X11 (method of farming), X12 (lack of technology to process the crop). This implies that famers rank these indicators highly to be a major factor related to post harvest losses. Hence the first factor is term the lack of knowledge and technology related factors. The second factor has its high loadings on X3 (cost of transportation), X4 (inadequate Market for the crop), and X5 (fertilizer and chemical used). This factor turns to be related to how much a famer spent during harvesting. Therefore, the second factor would be dfficulties in market accessibility related factors.

The high loadings in factor three were recorded by indicator X1 (the size of the farm), and X2 (labour cost). It could be well-known that these indicators have something to do with the quality and application of fertilizers'; therefore these are enough to explain the factor labour cost related factors. The next factor, factor four has high loadings on X14 (improper market facilities), and X15 (poor packaging). They 
appear to have the highest loadings from the factor matrix. However, these factors relate to difficulties respondents' feel on the road and in the market due to the poor packaging of the produces, thus the forth factor is termed lack of storage facilities and poor packaging related factors. The fifth factor has its high loadings on X16 (poor road network). This indicator however is related to the respondents farm management system, hence will be enough to explain the fifth factor as poor road network related factors. Present the factors in order of importance. This can be done by observing the table below.

Table 7. Varimax Transformation Matrix

\begin{tabular}{lccccc}
\hline Component & $\mathbf{1}$ & $\mathbf{2}$ & $\mathbf{3}$ & $\mathbf{4}$ & $\mathbf{5}$ \\
\hline 1 & 0.52 & $\mathbf{0 . 5 9}$ & 0.27 & 0.08 & 0.55 \\
2 & $\mathbf{0 . 6 1}$ & -0.70 & 0.02 & -0.30 & 0.22 \\
3 & 0.01 & -0.26 & -0.35 & $\mathbf{0 . 8 4}$ & 0.31 \\
4 & 0.60 & 0.24 & -0.37 & 0.15 & $-\mathbf{0 . 6 5}$ \\
5 & 0.09 & -0.18 & $\mathbf{0 . 8 2}$ & 0.41 & -0.35 \\
\hline
\end{tabular}

The Varimax transformation matrix shows that the second factor difficulties in market accessibility related factors is the most important factor of all, thus this is the major factor accountable for high post harvest losses in the agriculture industry. The next most important factor accountable for post harvest losses is inadequate information about the crop and lack of technology to process the products are the first factor lack of knowledge and technology related factors. The fourth factor lack of storage facilities poor packaging related factors is the third important factor accountable for post harvest losses. The fourth most important factor is the fifth factor poor road network related factors. And lastly, the least most important factor is the third factor labour cost related factors in describing the factors accountable for post harvest losses.

Various attempts to suppress losses the results still have to be done. One of opportunities to suppress losing results by optimizing utilization tools for harvest, and post-harvest that is in area. Post harvest handling is strategic activities that require participation whole society (Kobarsih and Siswanto, 2015). Postharvest technology for pressing lost important yields applied at the farmer level. Therefore, farmers need to be encouraged to use technology which are available. Problems in the application of technology post-harvest is not a minimum the application of technology by farmers, however in the form of non-technical and social problems. Harvest time is often determined by the collectors whose exceeds the number ideally so the yields a lot scattered. Besides that, not all farmers able and willing to apply technology postharvest due to ability factors and local culture. Institutional farmers are mostly still oriented to get facilities from the government, not fully put in effort take advantage of these institutions as a support for economic activity (Iswari, 2012).

\section{CONCLUSION}

There are five salient factors that influence post harvest losses, lack of knowledge and technology related factors, difficulties in market accessibility related factors, labour cost related factors, lack of storage facilities and poor packaging related factors, and poor road network related factors. The respondents rated difficulties in market accessibility related factors as most important follow by lack of knowledge and technology related factors, lack of storage facilities and poor packaging related factors, 
poor road network related factors and labour cost related factors respectively. When these factors are managed very effectively there will be reduction in post harvest losses, without necessarily importing additional food.

\section{REFERENCES}

Darwis, V. (2018) 'Potensi kehilangan hasil panen dan pasca panen jagung di Kabupaten Lampung Selatan', Journal of Food System and Agribusiness, 2(1), pp. 55-67. doi: http://dx.doi.org/10.25181/jofsa.v2i1.1054.

Iswari, K. (2012) 'Kesiapan teknologi panen dan pascapanen padi dalam menekan kehilangan hasil dan meningkatkan mutu beras', Jurnal Litbang Pertanian, 31(2), pp. 58-67. doi: 10.21082/jp3.v31n2.2012.p\%25p.

Karim, A. and Wee, M. (1996) 'Reducing post harvest losses in vegetables', in Proceedings of Workshop on Vegetable Crops Agribusiness, pp. 2-4.

Kereth, G. A. et al. (2013) 'Assessment of post-harvest handling practices: Knowledge and losses of fruits in Bagamoyo District of Tanzania', Food Science and Quality Management, 11, pp. 8-16. Available at: https://www.iiste.org/Journals/index.php/FSQM/article/view/3951.

Kobarsih, M. and Siswanto, N. (2015) 'Penanganan susut panen dan pasca panen padi kaitannya dengan anomali iklim di wilayah Daerah Istimewa Yogyakarta', Planta Tropika Journal of Agro Science, 3(2), pp. 100-106. doi: 10.18196/pt.2015.046.100-106.

Olayemi, F. F. et al. (2012) 'Assessment of post harvest losses of some selected crops in eight local government areas or Rivers State, Nigeria', Asian Journal of Rural Development, 2(1), pp. 13-23. doi: 10.3923/ajrd.2012.13.23.

Robinson, E. J. and Kolavalli, S. L. (2010) The case of tomato in Ghana: Productivity. Washington, D.C.: International Food Policy Research Institute (IFPRI).

Shiddieqy, M. and Widiani, W. (2012) 'Kontribusi penanganan pasca panen wortel terhadap pendapatan petani sayuran binaan Sub Terminal Agribisnis (STA) Cigombong Desa Ciherang Kabupaten Cianjur', Journal of Agroscience, 4, pp. 74-84. Available at: https://jurnal.unsur.ac.id/agroscience/article/view/305.

Tefera, T. (2012) 'Post-harvest losses in African maize in the face of increasing food shortage', Food Sec, 4, pp. 267-277. doi: 10.1007/s12571-012-0182-3.

Verma, A. and Singh, K. (2004) 'An economic analysis of post-harvest losses in fresh vegetables', Indian Journal of Agricultural Marketing, 18(1), pp. 136-139.

World Bank (2011) Missing Food: The Case of Post harvest Grain Losses in SubSaharan Africa. Washington, D.C. 